Ks. Jerzy DUDA

(Warszawa, UKSW)

\title{
KONCEPCJA NAUCZANIA I WYCHOWANIA WE WCZESNOCHRZEŚCIJAŃSKIEJ SZKOLE ORYGENESA
}

Orygenes z Aleksandrii (ok. 185-254), jeden z najwybitniejszych teologów wczesnochrześcijańskich, zostawił bez wątpienia swoje niewidzialne piętno na kształcie dzisiejszego Kościoła. Potępiony ${ }^{1}$ i zapomniany, odkryty na nowo przez Erazma z Rotterdamu ${ }^{2}$ i wskrzeszony przez teologów XX wie$\mathrm{ku}^{3}$, ciągle zachwyca i inspiruje. Adamantios ${ }^{4}$, bo tak go współcześni nazywali, był nie tylko niezrównanym egzegetą, teologiem i mistykiem ${ }^{5}$, lecz również wybitnym pedagogiem, prowadzona zaś przez niego szkoła stała się „kuźnią” męczenników, biskupów i nauczycieli ${ }^{6}$. Pierwszy historyk Kościoła, uważający się za jego ucznia, Euzebiusz z Cezarei (†339), z entuzjazmem opowiada o sławie Scholarchy z Aleksandrii: „Nieprzerwanym szeregiem jedni po drugich, od rana do wieczora przesuwali się przez jego szkołę"7. Zaskakuje nieco, że nie tylko chrześcijanie, czy katechumeni przygotowujący się do sakramentu chrztu, poszukiwali mądrości u Orygenesa, lecz również, jak zauważa

${ }^{1}$ Orygenes został formalne potępiony na Soborze Konstantynopolitańskim II w 553 roku. Jego pisma oraz imię, jako herezjarchy, znalazło się w jednym szeregu z Ariuszem, Eunomiuszem, Apolinarym, Macedoniuszem i obłożone anatemą, por. Concilium Constantinopolitanum II can. 11, Mansi IX 395-400 (Canones contra Origenem) lub Dokumenty soborów powszechnych, red. A. Baron - H. Pietras, ŹMT 24, Kraków 2001, 295: „Kto nie odrzuca Ariusza, Eunomiusza, Macedoniusza, Apolinarego, Nestoriusza i Orygenesa wraz z ich bezbożnymi pismami i wszystkich innych heretyków, którzy zostali potępieni i odrzuceni [...] niech będzie przeklęty"; S. Longosz, Orygenizm i spory wokót Orygenesa, VoxP 5 (1985) t. 8-9, 395-412; tenże, Orygenesowskie spory, EK XIV, Lublin 2010, 857-664 (bibliografia).

${ }^{2}$ Por. A. Godin, Erasme lecteur d'Origène, Genève 1982, cyt. za: H. Crouzel, Orygenes, thum. J. Margański, Kraków 2004, 323.

${ }^{3}$ Wśród badaczy Orygenesa znajdujemy nazwiska najwybitniejszych teologów XX wieku, zwłaszcza J. Daniélou, Origène, Paris 1948, oraz: H. de Lubac, S. Boulgakov, K. Rahner, czy też kardynał nominat H.U. von Balthasar.

${ }^{4}$ Przydomek nadany Orygenesowi przez jego współczesnych tłumaczy się zazwyczaj jako „człowiek ze stali”.

${ }^{5}$ Por. Crouzel, Orygenes, s. 93-322.

${ }^{6}$ Por. H. Pietras, Orygenes, Kraków 2001, 13.

${ }^{7}$ Eusebius, HE VI 15, SCh 41, 109, thum. A. Lisiecki, POK 3, 269. 
tenże Euzebiusz, „tysiące heretyków i wielu co najznakomitszych filozofów skwapliwie się do niego garnęło, biorąc u niego naukę, nie tylko w teologii, ale także w filozofii pogańskiej"8.

Didaskaleion stworzony przez Scholarchę z Aleksandrii, budzi wśród dzisiejszych badaczy starożytności wczesnochrześcijańskiej duże zainteresowanie, jednakże wiele kwestii z nim związanych nie doczekało się do tej pory gruntownego opracowania. Należy przypomnieć, iż działalność Orygenesa była przede wszystkim związana $\mathrm{z}$ dwiema instytucjami pedagogicznymi: pierwszą z nich była reorganizowana przez niego szkoła katechetyczna w Aleksandrii ${ }^{9}$, drugą zaś, po jego wypędzeniu, szkoła w Cezarei Palestyńskiej. W niniejszym opracowaniu, ze względu na wąskie ramy artykułu, chcielibyśmy scharakteryzować strukturę oraz koncepcję nauczania i wychowania stosowaną przez Adamantiosa jedynie w didaskaleionie w Cezarei Palestyńskiej, świadomie rezygnując z charakterystyki szkoły katechetycznej w Aleksandrii. Pierwszorzędnym źródłem w przedstawieniu tej problematyki jest dla nas Mowa pochwalna na cześć Orygenesa Grzegorza Cudotwórcy, który ją wygłosił w chwili swego odjazdu z Cezarei, po pięciu latach odbywanego tam nauczania $^{10}$ oraz Historia Ecclesiastica Euzebiusza z Cezarei, gdzie prawie cały VI rozdział poświęcony jest Adamantiosowi.

Orygenes w momencie, gdy znalazł się w Cezarei Palestyńskiej był już na tyle znany, iż „garnęło się do niego nie tylko wielu tamtejszych mieszkańców, ale $z$ dalekich nawet stron jego zwolennicy tysiącami opuszczali ojczyznę"1". Te słowa Euzebiusza, mimo retorycznej przesady, świadczą o wielkim uznaniu i popularności Scholarchy. Nie dziwi więc fakt, że sławny „nauczyciel

\footnotetext{
${ }^{8}$ Tamże VI 18, SCh 41, 112, POK 3, 271.

${ }^{9}$ Według świadectwa Euzebiusza z Cezarei, biskup aleksandryjski Demetriusz († 232) powierzył Orygenesowi, mającemu wówczas osiemnaście lat, prowadzenie szkoły katechetycznej. Wykłady prowadzone przez Scholarchę cieszyły się dużą popularnością, co owocowało napływem nowych uczniów. Indywidualna praca naukowa, jak również podjęte przez Adamantiosa dalsze studia świeckie, zmusiły go do przeprowadzenia reorganizacji zajęć. Orygenes powierzył nauczanie katechumenów swojemu uczniowi Heraklesowi, wcześniejszemu studentowi w szkole filozofa Ammoniusza Sakkasa, sam zaś zajmował się uczniami najbardziej zaawansowanymi w nauce, wykładając im, po odpowiednim przygotowaniu, filozofię i egzegezę biblijną, por. Eusebius, HE VI 18, SCh 41, 112, POK 3, 271; zob. Crouzel, Orygenes, s. 31-35.

${ }^{10}$ Grzegorz, nazywany w tradycji Kościoła Thaumaturgos - Cudotwórca, urodził się prawdopodobnie z Neocezarei, w krainie Pontu. Pochodził z pogańskiej rodziny i we wczesnej młodości stracił ojca. Po ukończeniu nauczania podstawowego oraz rozpoczętych studiach z dziedziny retoryki, postanowił studiować prawo w Bejrucie, sławnym w owym czasie ze znakomitej szkoły prawniczej. Wybrał się tam wraz ze swoim bratem Atenodorem. Droga wiodła przez Cezareę, gdzie ich szwagier pełnił funkcję radcy prawnego przy gubernatorze. Szwagier ów, poprosił Grzegorza o pomoc i towarzystwo jego żonie, w bezpiecznym dotarciu do Cezarei. Tam też nastąpiło spotkanie obu braci z Orygenesem, por. Gregorius Thaumaturgus, Oratio panegyrica in Origenem 5, 65-72, SCh 148, 120. 124, tłum. S. Kalinkowski, ŹMT 11, 57-58.

${ }^{11}$ Eusebius, HE VI 30, SCh 41, 132, POK 3, 285.
} 
Kościoła" ${ }^{12}$, przy poparciu miejscowego biskupa Teoktysta ${ }^{13}$, zgromadził wokół siebie uczniów i stworzył didaskaleion. Do dnia dzisiejszego trwa jednak naukowa dyskusja na temat jego charakteru i struktury instytucjonalnej. Jedni uczeni widzą w nim pierwszą akademię teologii chrześcijańskiej ${ }^{14}$, inni zaś tylko szkołę katechetyczną ${ }^{15}$. Ciekawe poglądy w tej kwestii przedstawia $\mathrm{H}$. Crouzel $^{16}$, który uważa, idąc za A. Knauberem ${ }^{17}$, iż didaskaleion Orygenesa był instytucją przypominającą w jakimś stopniu szkołę misyjną, w której nauka była skierowana do młodych pogan sympatyzujących z chrześcijaństwem, nie obligującą ich jednak do przyjęcia chrztu. Crouzel uzasadnia swoje stanowisko między innymi badaniami nad nauką chrystologiczną, zawartą w Mowie pochwalnej na cześć Orygenesa Grzegorza Cudotwórcy, zwracając uwagę na to, iż Grzegorz nie przedstawia pełnej doktryny chrześcijańskiej, a tylko te jej aspekty, które daje się wyrazić w kategoriach filozoficznych. Prowadzi to do wniosku, iż Orygenes nauczając filozofii, inspirowanej głównie średnim platonizmem, jedynie wprowadzał swych uczniów w chrześcijaństwo, do pełnego zaś poznania prawd wiary oraz przyjęcia chrztu musieliby oni przejść dodatkowo kościelną katechizację. Powyższa argumentacja budzi jednak pewne zastrzeżenia. Mowa wygłoszona przez Grzegorza nie ma charakteru kerygmatycznego, lecz jest jedynie podziękowaniem Scholarsze za lata nauki. Jest zatem zrozumiały brak w niej pełnego przedstawienia określonych aspektów doktryny Kościoła prezentowanej przez Adamantiosa. Warto również zauważyć, że Mowa miała zapewne charakter publiczny, a zatem forma przekazu była prawdopodobnie dostosowana do szerokiego audytorium, niekoniecznie chrześcijan, z uwzględnieniem obowiązującej jeszcze w owym czasie misteryjności przekazu doktryny.

Istnieją pewne przesłanki wskazujące, iż w strukturze stworzonego w Cezarei didaskaleionu mogłyby się znaleźć niejako dwie formy instytucjonalne, odpowiadające swym kształtem charakterowi przekazywanej nauki. Pierwsza z nich nie różniłaby się od istniejących w ówczesnym czasie instytucji naukowych, skierowanych do ludzi, w większości młodych, poszukujących wiedzy i mądrości. Potwierdzeniem takiego stanu rzeczy może być fakt, iż do didaskaleionu Orygenesa zostali przyjęci Grzegorz Cudotwórca oraz jego brat Atenodor, którzy prawdopodobnie nie będąc jeszcze chrześcijanami, niejako ,z ulicy”, wiedzeni jedynie ciekawością, trafili do jego szkoły, uczestniczyli w otwartych wykładach, spotkali się ze Scholarchą i oczarowani siłą jego argumentacji postanowili studiować filozofię. Grzegorz opisuje do-

${ }^{12}$ Por. Pamphilius, Apologia pro Origene. Praefatio, PG 17, 547, thum. S. Kalinkowski, ŹMT 3, 40.

${ }^{13}$ Por. Eusebius, HE VI 27, SCh 41, 129, POK 3, 283.

${ }^{14}$ Por. M. Michalski, Antologia literatury patrystycznej, I, Warszawa 1975, 332-335 („Pierwsza Akademia Teologii Katolickiej").

${ }^{15}$ Por. J. Czuj, Szkoła Orygenesa, AK 42 (1950) t. 53, 114-129.

${ }^{16}$ Por. Crouzel, Orygenes, s. 53; tenże, L'Ecole d'Origène à Césarée, BLE 71 (1970) 15-27.

${ }^{17}$ Por. A. Knauber, Das Anliegen der Schule des Origenes zu Cäsarea, MThZ 19 (1968) 182-203. 
kładnie program nauczania, który przynajmniej we wstępnej swej fazie nie musiał wcale odbiegać od programu studiów filozoficznych, realizowanego w innych instytucjach pedagogicznych. Wydaje się, iż obok formy otwartych wykładów, stosowanej przynajmniej w pierwszym okresie nauki, mających strukturę i program podobny do innych istniejących w tym czasie instytucji naukowych, stworzył Orygenes inną, a mianowicie wspólnotę z najbliższymi uczniami i towarzyszami - prawie zakonną, w której żył, modlił się i pracował. Przesłankę ku takiemu założeniu możemy znaleźć w bardzo osobistych słowach jego ucznia Grzegorza:

„Głęboko poruszony tą miłością, postanowiłem porzucić wszystkie inne sprawy i wszelkie inne studia, które dotąd uznawałem za pożyteczne, wśród nich również moje ukochane prawo, a także moją ojczyznę i krewnych, zarówno mieszkających tutaj, jak i tych, których wcześniej opuściłem. Jedyną tylko rzecz uznałem za godną pożądania i miłości - filozofię, a także jej nauczyciela, tego oto boskiego człowieka"18.

Grzegorz do chwili przybycia do Cezarei miał już przed sobą wytyczony kierunek studiów, dlatego też zastanawia zmiana jego decyzji. Zafascynowanie filozofią i nauczycielem, nie nastąpiło u niego od razu, lecz po dłuższym czasie początkowego okresu nauczania ${ }^{19}$. Dopiero wtedy podjął decyzję o pozostaniu w szkole Orygenesa. Prawdopodobnie doprowadziło to do konfliktu w rodzinie, skoro Grzegorz napisał słowa o porzuceniu krewnych, mieszkających nie tylko $\mathrm{w}$ dalekim Poncie, ale również w tym samym mieście, a więc siostry i szwagra. Być może wybór filozofii, przepowiadanej przez Orygenesa na tym poziomie nauczania, łączyłby się już z przyjęciem chrztu i właśnie to zdarzenie doprowadziło do niezadowolenia rodziny, związanej ze strukturami państwowymi, niechętnymi przecież „,nowej” religii ${ }^{20}$. Faktem jest, że Grzegorz porzucił nie tylko swoje wcześniejsze plany, lecz również rodzinę, by zamieszkać we wspólnocie osób najściślej związanych ze Scholarchą i tam przez pięć najbliższych lat kontynuować swoją edukację. W retorycznym uniesieniu mówi, że miejsce to stało się dla niego prawdziwym domem, o którym wcześniej nie wiedział, a nauczyciel był jak ojciec, cieszący się szacunkiem i czcią swoich synów $^{21}$. Brak nam niestety źródeł historycznym mogących wiarygodnie scharakteryzować ,regułę”, program i rytm dnia tej wspólnoty. Wiemy jednak, iż czas dnia dzielony był na wykłady, czytanie Pisma Swiętego, pracę nad tekstami oraz modlitwę ${ }^{22}$. Prawdopodobnie dopiero na tym etapie nauczania wśród najbardziej zaawansowanych uczniów, Orygenes prowadził wykłady ściśle

\footnotetext{
${ }^{18}$ Gregorius Thaumaturgus, Oratio 6, 84, SCh 148, 128, ŹMT 11, 60.

${ }^{19}$ Por. tamże 6, 78, SCh 148, 126, ŹMT 11, 58.

${ }^{20}$ Według W. Jaegera (Wczesne chrześcijaństwo i grecka paideia, thum. K. Bielawski, Bydgoszcz 2002, 66-81) Orygenes i Klemens Aleksandryjski stali się twórcami filozofii chrześcijańskiej.

${ }^{21}$ Por. Gregorius Thaumaturgus, Oratio 16, 189, SCh 148, 174, ŹMT 11, 76.

${ }^{22}$ Por. tamże 16, 196, SCh 148, 178, ŹMT 11, 77.
} 
związane z chrześcijańskim wtajemniczeniem, egzegezą Pisma Świętego oraz wyjaśnianiem prawd wiary. Potwierdzenie faktu istnienia wspólnoty, w której żył i nauczał Orygenes w Cezarei, znajdujemy we fragmencie listu Hieronima do Marceli, w którym autor cytuje urywek listu nawróconego przez Orygenesa Ambrożego, który pisze:

„[... ] nigdy w obecności Orygenesa nie spożył pokarmu bez czytania, że nigdy nie zasnął, jeśli ktoś z braci nie czytał Pisma Świętego. Tak postępował we dnie i w nocy, by i czytanie wspierało modlitwę, i modlitwa czytanie"23.

Po próbie przedstawienie struktury instytucjonalnej didaskaleionu Scholarchy z Aleksandrii, postaramy się przybliżyć jego koncepcję nauczania i wychowania. Głównym założeniem paidei w szkole Orygenesa, było doprowadzenie ucznia, na drodze ściśle określonego procesu pedagogicznego, do spotkania ze zbawczym Słowem ${ }^{24}$. Wychowanie filozoficzne, które miało temu służyć, związane było z „nawróceniem”, w pierwotnym tego słowa znaczeniu, czyli na właściwym ukierunkowaniu duszy i zwróceniu się ku temu, co dobre. Widzimy tutaj bardzo wyraźną analogię do teorii paidei nakreślonej przez Platona w Państwie ${ }^{25}$. Według Platona kształcenie człowieka, przez właściwe zwrócenie się ku źródłu światła, czyli wiedzy, dążenie do mądrości, nabywanie cnoty filozoficznej, może zaowocować poznaniem teologicznym, a przez to upodobnieniem się do Absolutu ${ }^{26}$.

Program edukacji w szkole Orygenesa rozpoczynał się od indywidualnego rozeznania poziomu intelektualnego i umiejętności ucznia. Zwykle uczniowie posiadali już przynajmniej elementarną wiedzę z dziedziny filozofii, wyniesioną z wcześniejszych lat nauki, jednakże najczęściej była ona dość powierzchowna i chaotyczna. Grzegorz Cudotwórca, z perspektywy kilku lat spędzonych w didaskaleionie, przyrównał pracę Scholarchy do dobrego

${ }^{23}$ Hieronymus, Epistula 43, 1, ed. I. Hilberg, CSEL 54, 318, thum. J. Czuj: Listy, t. 1, Warszawa $1952,248$.

${ }^{24}$ Por. Gregorius Thaumaturgus, Oratio 6, 82, SCh 148, 128, ŹMT 11, 59.

${ }^{25}$ Por. Plato, Respublica VII 518c-e, ed. E. Chambry: Plato, Oeuvres complètes, t. 6: La République, Paris 1932, 151. Według teorii wychowania, nakreślonej przez Platona w Państwie, zdobycie wiedzy polegało na budzeniu zdolności tkwiących w duszy. Dokonuje się to przez proces nawrócenia, czyli zwrotu całej duszy ku jasności spływającej z idei Dobra, która jest praźródłem wszystkiego. Wstępnym etapem tej paidei jest matematyka, czyli nauka która pozwala odwrócić duszę od świata widzialnego, ku takiemu, który poznawać można jedynie rozumem. Matematyka pozwala na drodze dialektycznej krytyki doprowadzić do poznania prawd filozoficznych. Nauka dialektyki, jako „umiejętności uzasadniania i wnikania w przedstawione uzasadnienie", należy do najwyższego etapu paidei, jest jej zwieńczeniem i szczytem ludzkiej wiedzy, gdyż prowadzi do poznania sensu bytu, a więc również idei Dobra, zob. W. Jaeger, Paideia, thum. M. Plezia - H. Bednarek, Warszawa 201, 875-904.

${ }^{26}$ Platon jest uznawany za twórcę pojęcia teologii, pojmowanej jako rozumowe, a więc filozoficzne, roztrząsanie najdonioślejszych problemów bytu. Pojęcie teologii, jako wyższej i czystej formy poznania, jest u niego przeciwstawione religii ludowej, bazującej na mitologicznych wyobrażeniach i związanych z nimi tradycjach i obrzędach, por. Jaeger, Paideia, s. 878-882. 
rolnika, który ma do czynienia z trudną do uprawy ziemią. Zwykle jest ona dobra, ale zaniedbana, zarośnięta cierniami i ostami, wysuszona i zasolona, kamienista i piaszczysta ${ }^{27}$. Często przypomina ugór, ziemię zdziczałą, leżącą odłogiem, która, by zaczęła przynosić plony, wymaga wielkiego nakładu pracy, specjalistycznej wiedzy rolnika i jego zaangażowania ${ }^{28}$. Adamantios świadom takiego stanu rzeczy, w pracy z uczniami zastosował początkowo metodę dialektyczną, zaczerpniętą od Sokratesa ${ }^{29}$, a powszechnie stosowaną w owym czasie w greckich szkołach filozoficznych ${ }^{30}$. Polegała ona na dochodzeniu do prawdy na drodze stawiania pytań i szukania odpowiedzi, doprowadzających często do absurdu pierwotne błędne przekonania rozmówcy, na zestawianiu i porównywaniu przeciwstawnych stanowisk lub pokazywaniu wewnętrznych sprzeczności w poglądach, które wydawały się początkowo prawdziwe ${ }^{31}$. Przy istniejącej wielości nauk, dróg i metod zbliżenia się do poznania rzeczywistości krytyka dialektyczna dawała możliwość właściwej oceny ich założeń i twierdzeń oraz ukierunkowania ku poznaniu sensu bytu. Wiedza zatem, jaką dawała dialektyka, pozwalała uchwycić istotę prawd filozoficznych. Orygenes uczył więc swoich uczniów dogłębnej analizy, krytycznego podejścia oraz logicznego wyprowadzania wniosków z przeprowadzonych badań. Grzegorz pisał o tym w sposób następujący:

„Jak rolnik więc otoczył mnie swą umiejętną opieką, badał mnie dokładnie, nie poprzestając na tym, co dla wszystkich było widoczne na powierzchni, lecz wnikał głębiej, sięgając do wnętrza; zadawał pytania i słuchał odpowiedzi, a kiedy dostrzegał w nas coś, co nie było jałowe, nieużyteczne i próżne, kopał, orał, podlewał, spulchniał, wykorzystywał wszystkie swe umiejętności, troskliwie pielęgnował, za pomocą upomnień i zakazów wyrywał i usuwał osty, ciernie, chwasty, wszelkie dzikie rośliny, które rodziła moja niespokojna, nieporządna i lekkomyślna dusza" ${ }^{32}$.

Zastosowanie metody dialektycznej wymagało od Scholarchy dużej znajomości pedagogiki, delikatności i systematyczności. Niejednokrotnie w wirze dyskusji okazywało się, iż założenia przyjmowane początkowo za prawdziwe, okazywały się fałszywymi, a poglądy nie budzące zaufania, zawierały prawdę $^{33}$. Poczucie niewiedzy, zwodniczość poglądów, które przy bliższej analizie okazywały się sofizmatami, deprymowały uczniów ${ }^{34}$, dlatego też Orygenes z wielką osobistą życzliwością, cierpliwością i dobrocią starał się swoich słu-

\footnotetext{
${ }^{27}$ Por. Gregorius Thaumaturgus, Oratio 7, 93, SCh 148, 134, ŹMT 11, 61.

${ }^{28}$ Por. tamże.

${ }^{29}$ Por. tamże 7, 97, SCh 148, 137, ŹMT 11, 62.

${ }^{30}$ Por. Jaeger, Wczesne chrześcijaństwo, s. 70.

${ }^{31}$ Por. S. Kamiński, Dialektyka, EK III 1255-1256.

${ }^{32}$ Gregorius Thaumaturgus, Oratio 7, 95-96, SCh 148, 134-136, ŹMT 11, 62.

${ }^{33}$ Por. tamże 7, 102-104, SCh 148, 139, ŹMT 11, 62-63.

${ }^{34}$ Por. tamże 7, 98, SCh 148, 136, ŹMT 11, 62.
} 
chaczy właściwie zmotywować, rozbudzając w nich prawdziwie naukową pasję poznania prawdy oraz korzystania z dóbr, które dawała filozofia. Odkrycie własnej niewiedzy, czy błąd poznawczy, były jedynie przygotowaniem ,gleby duszy" do przyjęcia zdrowych ziaren słów prawdy. Scholarsze w przekazywaniu wiedzy służyła nie tylko logika argumentacji i kompetencja naukowa, lecz również zaufanie, jakim cieszył się wśród uczniów, i siła przyjaźni ${ }^{35}$.

Kolejnym etapem kształcenia w didaskaleionie Orygenesa były wykłady nauk przyrodniczych, dotyczące poznania otaczającej człowieka rzeczywistości, jego porządku i wspaniałości. Wśród nich ważne miejsca zajmowały nauki matematyczne, a w szczególności lubiana powszechnie przez uczniów geometria i astronomia ${ }^{36}$. Geometria wymagała myślenia ścisłego o przedmiotach rzeczywistych, a niewidzialnych. Według Platona, poznanie geometryczne zajmuje się dziedziną rzeczywistości istniejącej wiecznie ${ }^{37}$. Stąd wykorzystanie geometrii stało się doskonałym szczeblem w całokształcie filozoficznej paidei. Astronomia zaś, pozwalająca badać zjawiska i prawidłowości zachodzące na nieboskłonie, jest drogą wiodącą ku rzeczywistości Boga. Według relacji Grzegorza Cudotwórcy, Adamantios, w swoich wykładach przedstawiał nie tylko naukę przyjętą od innych uczonych, lecz również własne przemyślenia, poparte jasną i wiarygodną argumentacją. Problematyka, odnosząca się do świata, natury poszczególnych rzeczy, zmian zachodzących w szeroko rozumianym kosmosie, w zamierzeniu Orygenesa miała nie tylko fascynować, lecz także prowadzić do dostrzeżenia w rzeczywistości stworzonej działania Bożej Opatrzności ${ }^{38}$.

Szczególną dziedziną studiów w didaskaleionie Adamantiosa, podobnie jak i w innych szkołach filozoficznych, była etyka, oparta na boskich „,cno-

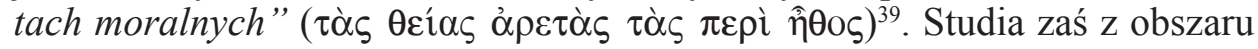
aretologii koncentrowały się wokół czterech cnót kardynalnych: roztropności, umiarkowania, sprawiedliwości i męstwa. Orygenes starał się nie tylko przekazać o nich wiedzę, ale bazując na własnych doświadczeniach z dziedziny duchowości, nauczyć swoich uczniów według nich żyć. Zdobycie cnót - uczył Scholarcha - jest potrzebne zarówno dla wewnętrznego pokoju, jak również dla duchowej równowagi. Adamantios, w relacji Grzegorza Cudotwórcy, nabiera cech wytrawnego psychologa, który podejmował wykłady o tematyce związanej z ludzkim charakterem, temperamentem, emocjami oraz sposobem właściwego ich kierowania. Poznanie siebie, własnych namiętności i popę-

${ }^{35}$ Por. tamże 6, 81, SCh 148, 128, ŹMT 11, 59.

${ }^{36}$ Por. tamże 8, 112-114, SCh 148, 142, ŹMT 11, 64.

${ }^{37}$ Por. Plato, Respublica VII 527b, ed. E. Chambry, s. 164-165.

${ }^{38}$ Wartość nauk przyrodniczych, wśród których szczególne miejsce zajmowała matematyka i znaczenie jej w całokształcie filozoficznej paidei, była podkreślana w wielu antycznych szkołach filozoficznych. Na gmachu Akademii Platońskiej miał być umieszczony napis: „Niech tu nie wchodzi nikt nie obeznany z geometrią", por. Jaeger, Paideia, s. 882-892.

${ }^{39}$ Por. Gregorius Thaumaturgus, Oratio 9, 115, SCh 148, 142, ŹMT 11, 64. 
dów, było drogą do przezwyciężenia wewnętrznej dysharmonii i osiągnięcia duchowego pokoju, charakterystycznego dla ludzi świętych i bliskich Bogu ${ }^{40}$. Grzegorz pisze o tym w następujący sposób:

„Starał się, aby nasza dusza, oglądając się jak w zwierciadle, zdołała dostrzec same początki i korzenie zła - całą swą niewiedzę, z której rodzą się w nas nierozumne namiętności, a także aby ujrzała swą cząstkę najlepszą, cząstkę rozumną, pod której przewodem dusza trwa niewzruszona i nie doznaje żadnej szkody"4l.

Prawda o własnym wnętrzu oraz namiętnościach, rządzących popędami, pozwala człowiekowi właściwie zdiagnozować źródło „złego pierwiastka”, odwrócić się od niego i świadomie odrzucić to, co zniewala, poniża i gnębi. Zdaje się, iż Orygenes próbował zaszczepić w uczniach ideał apatii ( $\alpha \pi \alpha ́ \theta t \alpha)$, jako beznamiętności cechującej prawdziwego filozofa, tak charakterystyczny dla szkoły stoickiej ${ }^{42}$. Również w Mowie Grzegorza znajdujemy bezpośrednie stwierdzenie na ten temat:

„Chciał nas uwolnić od trosk, chciał nas uczynić niewrażliwymi na wszelkie nieszczęścia, powściągliwymi i opanowanymi $[\ldots]^{\prime \prime 43}$.

W innym miejscu zaznacza, że Orygenesowi zależało na tym, by uczniowie poznając siebie: „odrzucili przyjemności i pożądania, smutki i obawy oraz cały szereg nieszczęść, które za nimi idą" ${ }^{44}$. Wyszczególnione przez Grzegorza

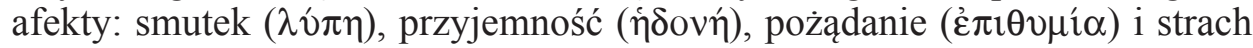
( $\varphi o ́ ß ం \varsigma)$, są charakterystyczne dla stoickiej doktryny, namiętności zaś postrzegane są w niej jako irracjonalne i nienaturalne ${ }^{45}$. Namiętności, które rodzą się przede wszystkim ze zła i niewiedzy, jak choroba opanowują duszę człowieka, wiążąc ją z rzeczami zewnętrznymi, które nie stanowią prawdziwych wartości. Umiejętność opanowania afektów i zobojętnienie na wszelkie dobra życiowe pozwala filozofowi, według Orygenesa, poddać się pod panowanie rozumu, kierować się w postępowaniu rozsądną trzeźwością oraz osiągnąć stan moralnej wolności i niezależności. Z najlepszej cząstki duszy, określanej jako rozumna, rozwijają się boskie cnoty:

„W ten sposób mogą powstać w duszy boskie cnoty: roztropność, która jako pierwsza jest zdolna do rozróżniania poruszeń duszy i dzięki temu do poznania, co jest dobre i co złe w świecie zewnętrznym; powściągliwość, to znaczy

${ }^{40}$ Por. tamże 9, 116-118, SCh 148, 144, ŹMT 11, 65.

${ }^{41}$ Tamże 11, 119, SCh 148, 144, ŹMT 11, 65.

${ }^{42}$ Por. G. Reale, Historia filozofii starożytnej, III, thum. E.I. Zieliński, Lublin 1999, 428-436;

W. Tatarkiewicz, Historia filozofii, I, Warszawa 2001, 132-135.

${ }^{43}$ Gregorius Thaumaturgus, Oratio 9, 116, SCh 148, 144, ŹMT 11, 65.

${ }^{44}$ Tamże 9, 120, SCh 148, 144, ŹMT 11, 65.

${ }^{45}$ Por. F. Copleston, Historia filozofii, I, thum. H. Bednarek, Warszawa 2004, 358-363. 
zdolność dokonywania od początku prawidłowego wyboru; sprawiedliwość, która oddaje każdemu to, co mu się należy; i wreszcie dzielność, która pozwala utrzymać i zachować pozostałe cnoty"46.

Grzegorz Cudotwórca, omawiając pokrótce poszczególne cnoty, tłumaczył, iż podobną wiedzę można zdobyć również w innych szkołach filozoficznych, jednakże tam jest ona podawana jedynie na sposób teoretyczny. Adamantios zaś, rezygnując z uczonych dywagacji na temat teorii cnót, zachęcał własnym przykładam do postępowania zgodnie z nimi ${ }^{47}$. Starał się być dla uczniów

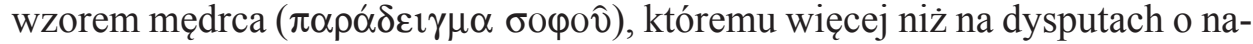
miętnościach, zależało na opanowaniu przez nich sztuki samokontroli, a jeżeli mówił o cnotach, to przede wszystkim dlatego, by jego słuchacze nauczyli się postępować sprawiedliwie, mądrze, powściągliwie i mężnie.

Zasadnicze miejsce w katalogu cnót, przytoczonym przez Grzegorza, zajmowała cnota roztropności ( $\varphi \rho o ́ v \varepsilon \sigma \iota \varsigma)$, rozumiana jako wiedza o tym, co należy czynić, a czego unikać, co jest dobre, a co jest dla człowieka szkodliwe. Roztropność daje człowiekowi możliwość spojrzenia w siebie jak w zwierciadło, pozwalając poznać samego siebie, dostrzec Boże podobieństwo i tą droga

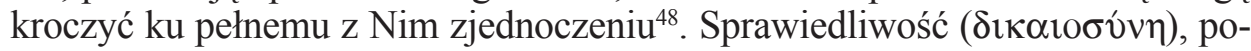
strzegana przez dawnych filozofów jako cnota dająca szczęście, polega na od-

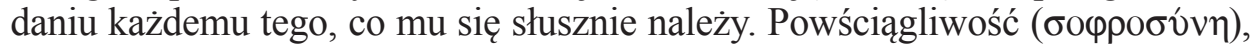
albo inaczej umiarkowanie, to nic innego, jak utrwalenie w sobie roztropności, zaś dzięki cnocie dzielności ( $\alpha v \delta \rho \varepsilon i ́ \alpha)$, człowiek jest zdolny wytrwać przy obranych wartościach i na nich budować swoje postępowanie. Wolny od strachu, smutku, nacisków czy różnych trudnych sytuacji życiowych człowiek pozostaje niezłomny i szczęśliwy ${ }^{49}$. Orygenes cnotę dzielności wiąże z chrześcijańską wytrwałością w wierze ${ }^{50}$. Według Adamantiosa, wszystkie cnoty rodzą się i mogą być zdobyte tylko dzięki cnocie pobożności. Człowiek będąc pobożnym może zbliżyć się do samego Boga, który jest źródłem wszelkich cnót. Pobożność zakłada uprzednie przezwyciężenie w sobie namiętności i zła. Zachodzi zatem pod jej wpływem do swoistego procesu wewnętrznego oczyszczenia, który sprawia, iż umysł upodabnia się do Boga i przy nim trwa ${ }^{51}$. Możemy zauważyć, iż w Orygenesowym wykładzie etyki dochodzi do spotkania greckiej myśli filozoficznej ze specyficzną doktryną chrześcijańską, przy czym to właśnie teologia daje pełne uzasadnienie i jest zwieńczeniem aretologii.

Najważniejszym i centralnym zagadnieniem, poruszanym w trakcie studiów w didaskaleionie Orygenesa, była metafizyczna problematyka, związana z po-

\footnotetext{
${ }^{46}$ Gregorius Thaumaturgus, Oratio 9, 122, SCh 148, 146, ŹMT 11, 65.

${ }^{47}$ Por. tamże 9, 124-126, SCh 148, 146, ŹMT 11, 66.

${ }^{48}$ Por. tamże 11, 141-142, SCh 148, 152, ŹMT 11, 68-69.

${ }^{49}$ Por. tamże 11, 143-144, SCh 148, 154, ŹMT 11, 69.

${ }^{50}$ Por. tamże 12, 149, SCh 148, 156, ŹMT 11, 70.

${ }^{51}$ Por. tamże.
} 
znaniem pierwszej przyczyny wszechrzeczy ${ }^{52}$. Punkt wyjścia stanowiły studia filozoficzne, dotyczące w szczególności pism tych mędrców i poetów, które mówiły o Bogu. Adamantios wyłączył jednak ze spisu lektur dzieła ateistów, uważając, iż nie zasługują one na uwagę uczniów. Twierdzenia tych, którzy odrzucają prawdę o istnieniu Boga i rządzącej kosmosem Opatrzności, sprzeciwiają się według niego nie tylko czci Boga oraz powszechnemu przekonaniu, ale również nie są warte naukowej analizy, niosąc w sobie niebezpieczeństwo zepsucia umysłu. Poza tym wyjątkiem, Orygenes zachęcał do studiowania wszystkich innych filozofów, nie preferując, ani nie odrzucając z góry określonej szkoły czy doktryny. Grzegorz Cudotwórca poświadcza, iż studenci mieli niejako obowiązek zapoznania się z nauką wszystkich znanych szkół filozoficznych ${ }^{53}$. Orygenesowi zależało na tym, by studenci gruntownie badając systemy filozoficzne, nauczyli się krytycznej analizy oraz dedukcyjnej syntezy. Pobieżne studia nad nauką określonej szkoły filozoficznej nie są w stanie właściwie ocenić jej doktryny, zaś liczne sofizmaty w niej zawarte mogą zniewolić umysł do tego stopnia, iż uzna on poglądy fałszywe za prawdziwe, przyjęte zaś pod jego wpływem przekonanie, będzie rzutować na całokształt światopoglądu studenta. Adamantios był świadomy tego, iż błąd poznawczy może odcisnąć się w umyśle niczym pieczęć, zniewalając przekonania i oddziałując na dalsze studia ${ }^{54}$. Niebezpieczeństwo pobłądzenia $\mathrm{w}$ gąszczu doktryny może być również wynikiem świadomego działania nauczyciela, który fanatycznie zapatrzony we własne odkrycia, zwodzi swoich zwolenników, nie chcąc uznać logicznej argumentacji i wniosków badawczych innych filozofów. Jako przykład Grzegorz podaje w swojej Mowie relacje, zachodzące prawdopodobnie pomiędzy szkołą platońską, a stoicką ${ }^{55}$. Orygenes postępował zupełnie inaczej:

„Nasz mistrz nie prowadził nas do jednego tylko systemu filozoficznego i nie pozwalał zatrzymać się przy jednej szkole, lecz oprowadził nas po wszystkich, każąc nam poznać wszystkie systemy filozofii greckiej. Sam zaś kroczył na czele jak podczas wędrówki i jeśli pojawiała się gdzieś jakaś trudność, tajemnica albo niebezpieczeństwo, prowadził nas za rękę"s6.

W takim sposobie wykładu przejawia się ogromna erudycja i pedagogiczne doświadczenie Orygenesa. Przeprowadzana przez niego charakterystyka i analiza poglądów poszczególnych filozofów pomagała studentom obiektywnie ocenić wartość naukową ich systemów. Scholarcha dogłębnie omawiał doktryny szkół filozoficznych, wydobywając z nich to, co było w nich pożyteczne i prawdziwe ${ }^{57}$. Taki sposób wykładu wymagał również od nauczyciela

\footnotetext{
${ }^{52}$ Por. tamże 13, 150, SCh 148, 158, ŹMT 11, 70.

${ }^{53}$ Por. tamże 13, 153-154, SCh 148, 158. 160, ŹMT 11, 71.

${ }^{54}$ Por. tamże 13, 155, SCh 148, 160, ŹMT 11, 71.

${ }^{55}$ Por. tamże 14, 160, SCh 148, 162, ŹMT 11, 72.

${ }^{56}$ Tamże 14, 170-171, SCh 148, 166, ŹMT 11, 73.

${ }^{57}$ Por. tamże 14, 172-173, SCh 148, 166-168, ŹMT 11, 73.
} 
poruszenia kwestii newralgicznych oraz kontrowersyjnych. Adamantios nie uciekał od tematów trudnych, kompetentnie wyjaśniając niespójności oraz bezlitośnie obnażając fałszywe założenia i błędy, szczególnie dotyczące kwestii teologicznych oraz moralności.

Wydaje się, iż wykłady dotyczące poglądów różnych szkół filozoficznych oraz analiza pism mędrców miały jedynie charakter pomocniczy, stając się naturalną introdukcją do przekazania uczniom najważniejszej prawdy o Bogu, jako pierwszej przyczynie wszechrzeczy. Wiedzę na ten temat czerpał Scholarcha z pierwszorzędnego źródła poznania, jakim była dla niego Biblia. Wśród licznych charyzmatów, jakie Grzegorz Cudotwórca odnalazł w swoim nauczycielu, najistotniejszą wydaje mu się umiejętność egzegezy Słowa Bożego:

„Ten człowiek otrzymał największy dar od Boga i uzyskał najlepszy los z niebios: jest tłumaczem słów Bożych wobec ludzi, rozumie sprawy Boże tak, jakby mu je Bóg tłumaczył, i opowiada o nich ludziom tak, aby je rozumieli"s8 .

Biblia jawi się uczniom didaskaleionu jako Księga pełna niejasności i zagadek. By zgłębić tajemnice proroctw w niej zawartych, zrozumieć wszelkie alegorie i treści mistyczne potrzebowali oni dobrego komentatora i przewodnika. Takim był dla nich Adamantios. Jego znajomość Pisma Świętego była imponująca ${ }^{59}$. Według Grzegorza, był natchniony przez Boga tym samym darem, jaki posiadali ci, którymi posłużył się Stwórca, by przekazać ludziom swoje Słowo. Orygenes zachwycał uczniów nie tylko wiedzą biblijną, ale również umiejętnością jasnego i głębokiego wytłumaczenia trudnych fragmentów ${ }^{60}$. Egzegeza Pisma Świętego, wzbudzająca zachwyt bogactwem treści, chociaż miała charakter systematycznej nauki, zmierzała ostatecznie ku zbliżeniu uczniów do źródła mądrości, jakim jest sam Bóg. Scholarcha wykładając naukę Biblii sprawiał, iż nawet Ci, którzy, poszukując jedynie mądrości, znaleźli się wśród jego uczniów, otrzymywali łaskę zrozumienia i wiary oraz podążali odtąd drogą Bożą ${ }^{61}$. Powyższe spostrzeżenie może być przesłanką do stwierdzenia, iż diadskaleion Orygenesa pełnił nie tylko funkcję edukacyjną, gdzie była wykładana „,filozofia chrześcijańska”, lecz stał się także miejscem nawracania uczniów oraz ich umacniania w wierze. Wydaje się, iż wykłady z dziedziny teologii, oparte na wnikliwej egzegezie Pisma Świętego, wieńczyły cykl nauczania w szkole Adamantiosa.

Podsumowując charakterystykę didaskaleionu Orygenesa w Cezarei Palestyńskiej, należy zaznaczyć, iż pod tym określeniem kryje się nie tylko wczesnochrześcijańska instytucja edukacyjna, z określoną koncepcją nauczania i wychowania, ale również wytyczony przez Scholarchę kierunek myślo-

\footnotetext{
58 Tamże 15, 181, SCh 148, 170, ŹMT 11, 75.

${ }^{59}$ Por. Crouzel, Orygenes, s. 93-119.

${ }^{60}$ Por. Gregorius Thaumaturgus, Oratio 15, 179-180, SCh 148, 170, ŹMT 11, 74.

${ }^{61}$ Por. tamże 15, 178, SCh 148, 170, ŹMT 11, 74.
} 
wy. Mimo, iż skąpość źródeł nie pozwala jednoznacznie rozstrzygnąć kwestii jej struktury organizacyjnej: czy była ona jedynie prywatną szkołą, podobnie jak wiele szkół filozoficznych czy retorskich funkcjonujących w tej epoce, czy też, jak to się powszechnie uznaje - szkołą misyjną - dla młodych pogan, sympatyzujących z chrześcijaństwem, czy, jak sami uważamy, szkołą filozofii chrześcijańskiej, w której na różnych poziomach dokonywał się proces edukacyjny i ewangelizacyjny, to jednak posiadamy wiele wiadomości na temat metody nauczania, programu oraz założeń wychowawczych. Orygenes na wstępnym etapie prowadził ćwiczenia z zakresu logiki i dialektyki. Następnie wykładał nauki przyrodnicze, głównie matematyczne. Ważnym elementem studiów w didaskaleionie było nauczanie etyki, oparte na czterech cnotach kardynalnych: sprawiedliwości, roztropności, umiarkowaniu i dzielności. Scholarcha pragnął nie tyle przekazać o nich wiedzę teoretyczną, ile nauczyć według nich kształtować własną postawę życiową. Centralnym przedmiotem omawianym przez Adamantiosa była teologia. Najpierw uczniowie, pod przewodnictwem Orygenesa, gruntownie analizowali pisma i poglądy znanych poetów i filozofów (oprócz ateistów), by ostatecznie podjąć zagadnienia stricte teologiczne. Wykłady filozoficzne stanowiły jedynie introdukcję do studiowania Pisma Świętego, które koronowało pełny cykl edukacyjny.

Nie jesteśmy w stanie dokładnie stwierdzić, kiedy szkoła Orygenesa zakończyła swoją działalność, wiemy jednak, że była ona „kuźnią” świętych i męczenników, a echa kierunku myślowego tam ukształtowanego, mimo dramatycznego paradoksu potępienia po wiekach jej Scholarchy, przeniknęły naukę Kościoła i owocują po dzień dzisiejszy.

\section{THE CONCEPTION OF INSTRUCTION AND UPBRINGING IN THE EARLY CHRISTIAN SCHOOL OF ORIGEN}

\section{(Summary)}

Origen (about 185-254 AD), an outstanding theologian and scholar who, after being banned from Alexandria, set up didaskaleion in Palestinian Caesarea. This term concerns not only the early Christian educational institution with a particular teaching and upbringing conception, but also the pointed by Adamantios thought stream. At his early educational stage Origen organised logic and dialectics classes. Next he lectured sciences, mainly mathematical ones. One important element of studies in didaskaleion was teaching ethics, based on the following four virtues: justice, prudence, moderation and courage. The scholar intended not so much to share theoretical knowledge about the quoted virtues but to help students shape their life policy based on them. The main subject touched upon by Adamantios was theology preceded by philosophy lectures. The echoes of the thought stream created in Origen's School, in spite of the Scholar himself being condemned centuries later, have gone deeply into the ecclesial science and have borne fruit till today. 